\title{
Comparison of timber-house technologies and initiatives supporting use of timber in Slovenia and in Sweden - the state of the art
}

\author{
Manja Kitek Kuzman (1), \\ Dick Sandberg ${ }^{(2)}$
}

\begin{abstract}
Historically, Slovenia and Sweden have equivalent uses of timber in construction and a long tradition of timber engineering and architecture. Nevertheless, in spite of these similarities, the development path to reach a modern and industrialized use of timber in construction which allows a diversity of architectural expression and design possibilities has differed considerably between these two countries, after the function-based building regulations that were introduced in Europe nearly three decades ago. This paper gives an overview of some characteristic modern timber buildings in Slovenia and Sweden, and the different construction techniques that are used in these two countries. Successful initiatives supporting the use of timber in construction are also presented. The opportunities for the further development of sustainable timber constructions in Slovenia and Sweden lie in new production methods, high prefabrication, and energy-efficient and climate-effective architecture, besides partnership and increased responsibilities for planning, improved and systematic feedback of experience and team cooperation, as well as knowing users identity, values and life style.
\end{abstract}

Keywords: Architecture, Timber Construction, Technologies, Promotion Initiatives in timber construction began in the early 1990 s, and there is no end in sight - building with wood is booming. In addition, the systematic development of specialised production methods as well as digital design and fabrication techniques have raised timber construction to a new level of building without depleting resources. Wood in countless forms offers architects an inspiring overview of many species and engineered wood products, and also a look into the future of the next generation of woodbased materials and construction solutions for tall timber buildings. Today we are in a unique moment in architectural and building engineering history when changing world needs have asked us to question some of the fundamentals of how we have built in the last century and how we shall
(1) University of Ljubljana, Biotechnical Faculty, Department of Wood Science and Technology (Slovenia); (2) Luleå University of Technology, Wood Science and Engineering (Sweden)

@ Manja Kitek Kuzman (manja.kuzman@bf.uni-lj.si)

Received: Feb 08, 2017 - Accepted: Sep 08, 2017

Citation: Kitek Kuzman M, Sandberg D (2017). Comparison of timber-house technologies and initiatives supporting use of timber in Slovenia and in Sweden - the state of the art. iForest 10: 930-938. - doi: 10.3832/ifor2397-010 [online 2017-12-07]

Communicated by: Giacomo Goli build in the future.

Slovenia and Sweden preserving bio-cultural diversity have many similarities in terms of the importance of forests for their society, and both countries have a long tradition of sustainable forestry, the industrial refining of the raw material which forestry can provide, and historical by equivalent uses of timber in construction. In spite of these similarities in wood tradition (Fig. 1), the material development architecture, and the technological potential and function-based building regulations that were introduced in Europe nearly three decades ago, Slovenia and Sweden have chosen different paths to reach a modern and industrialized use of timber in construction which allows a diversity of architectural expression and design possibilities.

Examples of modern timber buildings in Slovenia and Sweden with successful implementation of initiatives supporting the use of timber in construction could be opportunities for the development of forward looking challenges facing European bio-based society in the coming decades.

This paper provides an overview of some characteristic modern timber buildings in Slovenia and Sweden, showing different construction techniques and architectural expressions that are used in these two countries. Initiatives for supporting the use of timber in construction in Slovenia and Sweden are also presented. The work is 


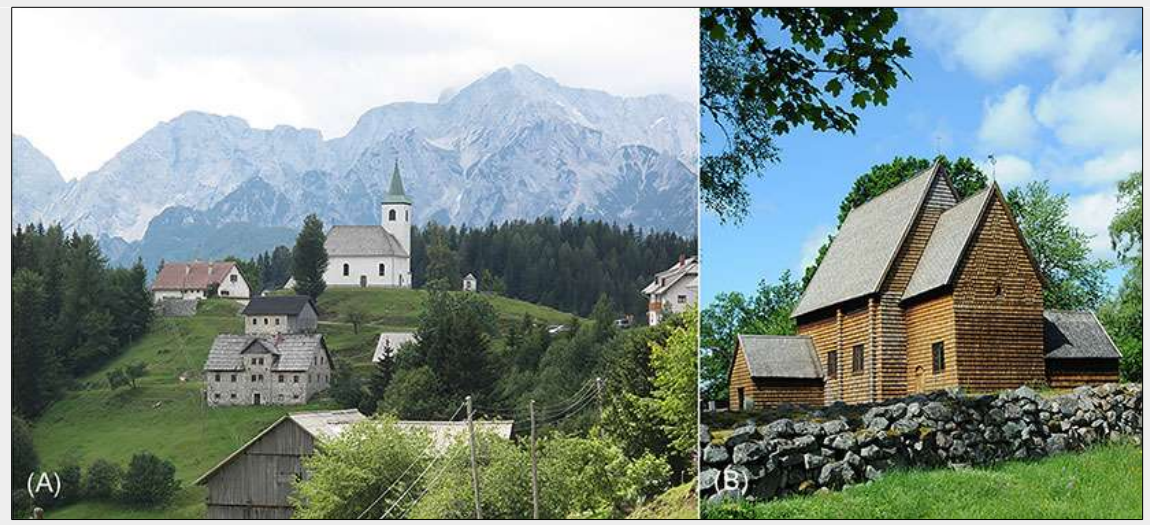

Fig. 1 - Historically equivalent uses of timber in construction: (A) wooden sheep farmers house from the $18^{\text {th }}$ century, Velika planina, Slovenia; (B) timber church from the $13^{\text {th }}$ century at Granhult, Sweden.

based on on-site visits to different construction sites for timber buildings, and interviews with persons deeply involved in modern timber construction in the two countries.

\section{Research}

\section{Development path to industrialized} timber construction

The development path to reach a modern and industrialized use of timber in construction which allows a diversity of architectural expression and design possibilities has differed considerably between Slovenia and Sweden.

In Slovenia, the predominant methods of timber construction include wood-panel, timber-frame, and cross-laminated timber (CLT) systems (Fig. 2). Wood-panel construction has been present in Slovenia for more than 35 years. Pre-fabricated construction started after World War II, when barracks were erected for the people who had been left without shelter and for those who had migrated from the countryside to the cities. However, in the past 30 years, timber construction has undergone major changes in Slovenia.

In timber-frame buildings, the basic verti- cal load-bearing elements are timber frames of glued-laminated timber (glulam). Panel-wall elements are mounted onto the frame construction and the exterior is covered with different wood-based or nonwood-based façade materials. Depending on the dimensions, one can distinguish between single-panel and macro-panel wall systems.

First developed in Switzerland in the 1970s, CLT is an extension of the technology that began with plywood. In the mid1990s, Austria undertook a joint industryacademia research effort that resulted in the development of modern CLT, and this product has since gained popularity in both residential and non-residential applications in Slovenia. In 2016, the global production

Considering the development as well as the impetuously growing interest and importance of CLT for architects, engineers and other stakeholders, an accelerated rise in worldwide production volume within the next decade is expected (Brandner et al. 2016).

In Slovenia, the first pre-fabricated houses were built in the early 1970s. They had very good thermal properties, thermal transmittance of the best panel-wall eleof CLT was $680,000 \mathrm{~m}^{3}$ (Ebner 2017). ments being much lower than provided by the regulations. For example, thermal insulation improved nearly three times from 1963 to 1972, and after 1992 it was almost four times better than specified by the then valid national regulations.

By 1992, the external wall elements met the requirements currently applicable in Slovenia regarding energy-efficient construction. The thermal transmittance of exterior walls was lower than the prescribed limit value of $0.28 \mathrm{~W} / \mathrm{m}^{2} \mathrm{~K}$, but had not reached the value for timber-frame constructions of $0.20 \mathrm{~W} / \mathrm{m}^{2} \mathrm{~K}$ (PURES 2010). Therefore, all prefabricated timber-framed structures set up before 1992 need renovation to enhance the energy efficiency of the building by 2020 .

In Sweden, it was not possible to use timber as a frame material in the construction of houses with more than two storeys until 1995. Regulations that regulated the choice of frame material excluded timber, as a result of a number of devastating fires in Swedish cities during the $19^{\text {th }}$ century. As a consequence, no development of multistorey timber building took place and other materials such as steel and concrete were used. Today, the use of timber as a material in multi-storey housing has increased to approximately $10 \%$ of all newly built multi-storey buildings. Developments towards an industrialised construction and manufacture within the timber building sector have in recent years led to an increase in prefabricated structural components of solid wood, engineered wood products (EWPs), and non-wood materials that are assembled at the construction site. The main timber-construction principles are the same in Sweden as they are in Slovenia.

In contrast to multi-storey housing, the industrial manufacture of single-family timber housing has a long tradition in Sweden. The factory manufacture of prefabricated timber houses began in Sweden during the 1800 , and a precursor to this method of manufacture was the activity of the architect Fredrik Blom (Eliasson et al. 2015). During the second half of the 1800 s and the
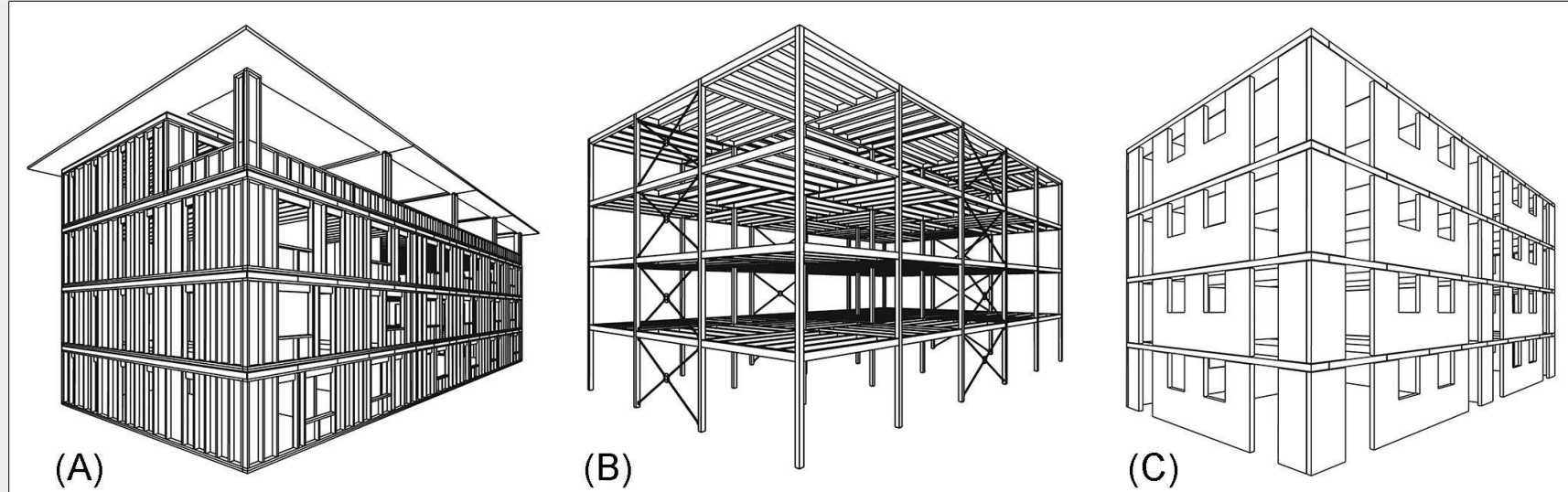

Fig. 2 - Timber-construction principles: (A) a wood-panel system; (B) a timber-frame system; and (C) a system based on CLT. 
early 1900s, numerous timber-house manufacturers emerged in Sweden. For several decades, about $90 \%$ of the on-site and prefabricated single-family houses built in Sweden have timber-frame systems, but this is not the case in the rest of Europe where less than $10 \%$ of the single-family houses have a timber framework (Dol \& Haffner 2010).

\section{Results}

Examples as a good practice of modern timber buildings and different construction techniques in Slovenia and Sweden are presented. Nowadays, modern timber buildings are an integral part of a new social reality based on individuality and flexibility as well as the affirmation of a new ecological sensibility (Gabrijelcic 2016). With a multidisciplinary approach, where design is only possible with the full cooperation between the building constructor, the wood engineer and the designer of the building, featuring technical disciplines as well as architecture as an art, it is possible to transform new timber building technology arrangements to healthy living spaces. The possibilities of such an approach are illustrated in Slovenia and Sweden by several examples of contemporary timber architecture using engineered wood products (EWPs).

\section{Engineered wood products in construction}

The primary engineered wood products (EWPs) used in timber construction in both Slovenia and Sweden range from laminated solid wood to various wood-based composites such as particleboard. In massive timber structures, glulam, CLT, laminated-veneer lumber (LVL), and laminated strand lumber (LSL) are used for walls, floors, and roofs. In timber-frame structures, timber wall sections are assembled from studs and crossbars of various dimensions. For the exterior and interior faces, besides solid wood various panel-based products are used. Including drywall panels and gypsum board, particleboard, cementbonded panels, fibreboard, oriented-strand boards (OSB), and LVL.

Although the production of CLT and its use in timber construction is increasing, the use of solid wood has lost its historical dominance and has been replaced by a number of EWPs which have made a significant contribution to the development of a new approach to contemporary architecture.

\section{Construction systems}

Several techniques are nowadays available for the construction of buildings with supporting frameworks of timber. A common way in both Slovenia and Sweden is to use structural timber members to form a frame which is covered by structural wood panels, where the foundations are generally of concrete. This building technique is often used in the construction of singlefamily houses, as well as in the construc-

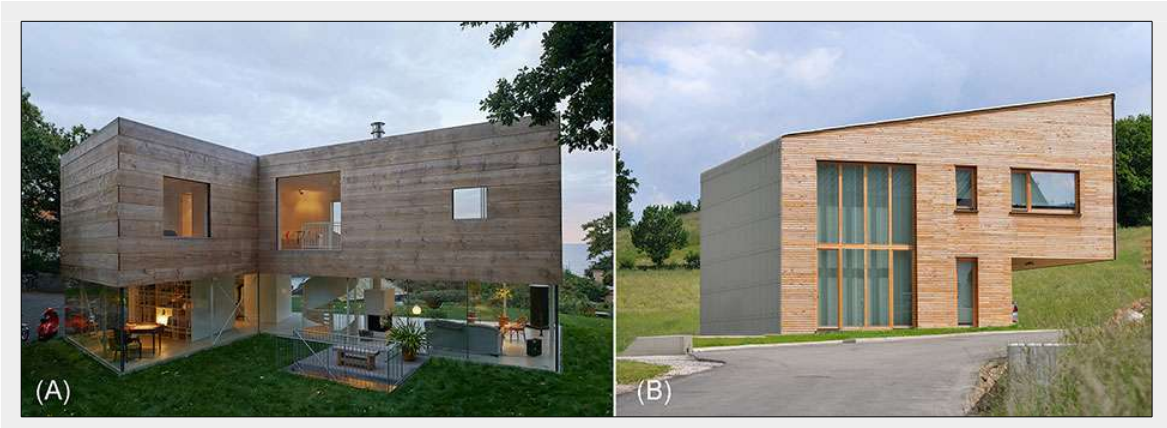

Fig. 3 - Several techniques are available for the construction of buildings with supporting frameworks of timber: a) the single-family building "Mölle by the sea" in Sweden, a steel structure, timber-frame, and CLT structure built in 2013, and b) "House Rant" in Slovenia, a timber-frame and CLT structure built in 2013.

tion of multi-storey buildings. Fig. 3 presents contemporary typologies design approach: purity of concepts and shapes, contemporary open spaces, technical solutions included into walls, ceilings, floors, and roofs.

Another technique uses CLT for the supporting framework. The external walls have a load-bearing and stabilizing function, and have to be insulated to give the building a high level of energy efficiency. Internal walls for stabilization are made of CLT, while sound-insulating walls between rooms are of traditional timber-frame structure. The most appealing reason for using the CLT system is to give the construction a high load-bearing capacity and high stiffness and more daring speculative proposals of the architectural design of the building. This technique is today bringing a wave of new design proposals to the construction of multi-storey buildings (Fig. 4).

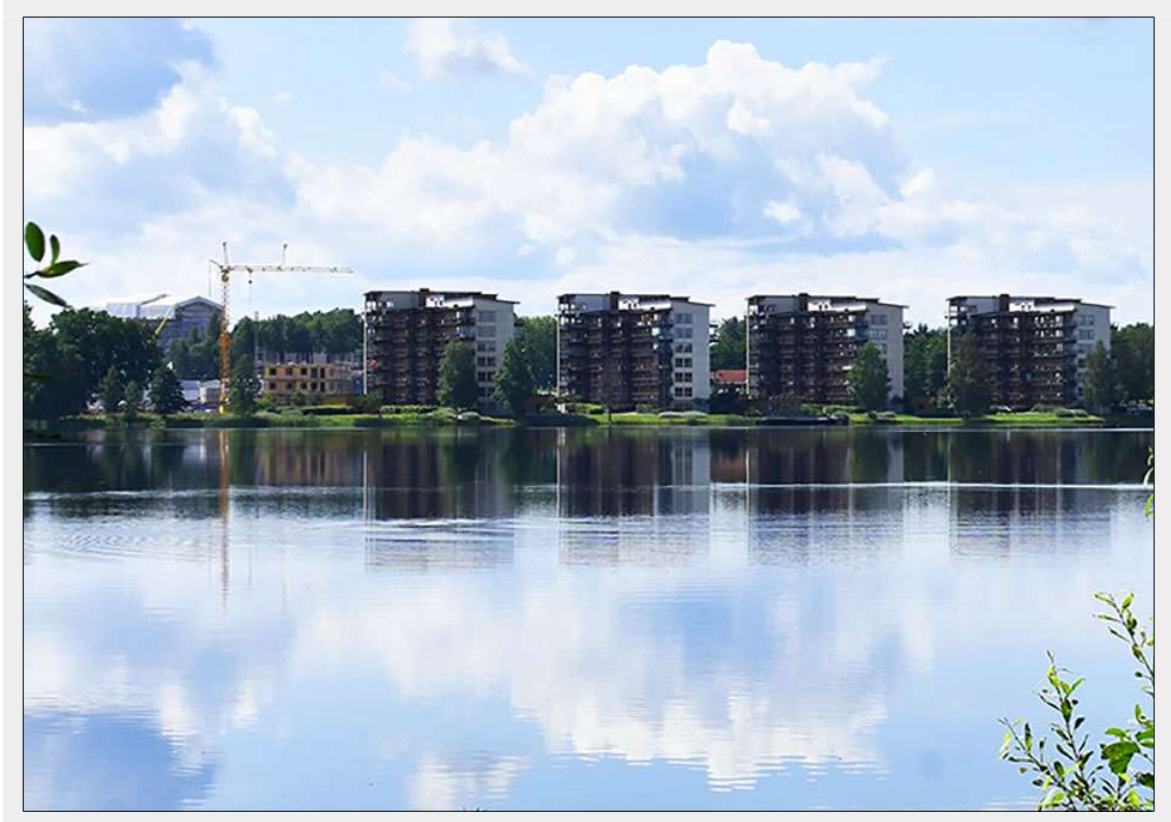

Fig. 4 - The use of CLT as load bearing, stabilizing and thermal insulating walls in modern multi-storey timber construction: "Limnologen", four 8-storey CLT buildings built during 2007-2009 in Växjö, Sweden (note the weather protection of the building under construction to the left).
A third technique is a system of columns and beams, where glulam is used to a large extent for the load-bearing structure. Not surprisingly, their initial use was for multistorey buildings following passive energy regimes, mainly building for industrial, storage or shopping centre use (Fig. 5).

The architecture is characterized by the use of different EWPs, and the building also has a clear environmental profile as design and technical solutions provide a building that meets the requirements for a low-energy building according to the EU's Green Building Program. Solar cells supply the building with electricity and remote cooling is connected. The building is characterized by a dynamic design that, among other things, is shaped with the building's visible wooden frame. The frame is a prefabricated timber beam system.

The primary criteria of modern timberconstruction systems are load-bearing 


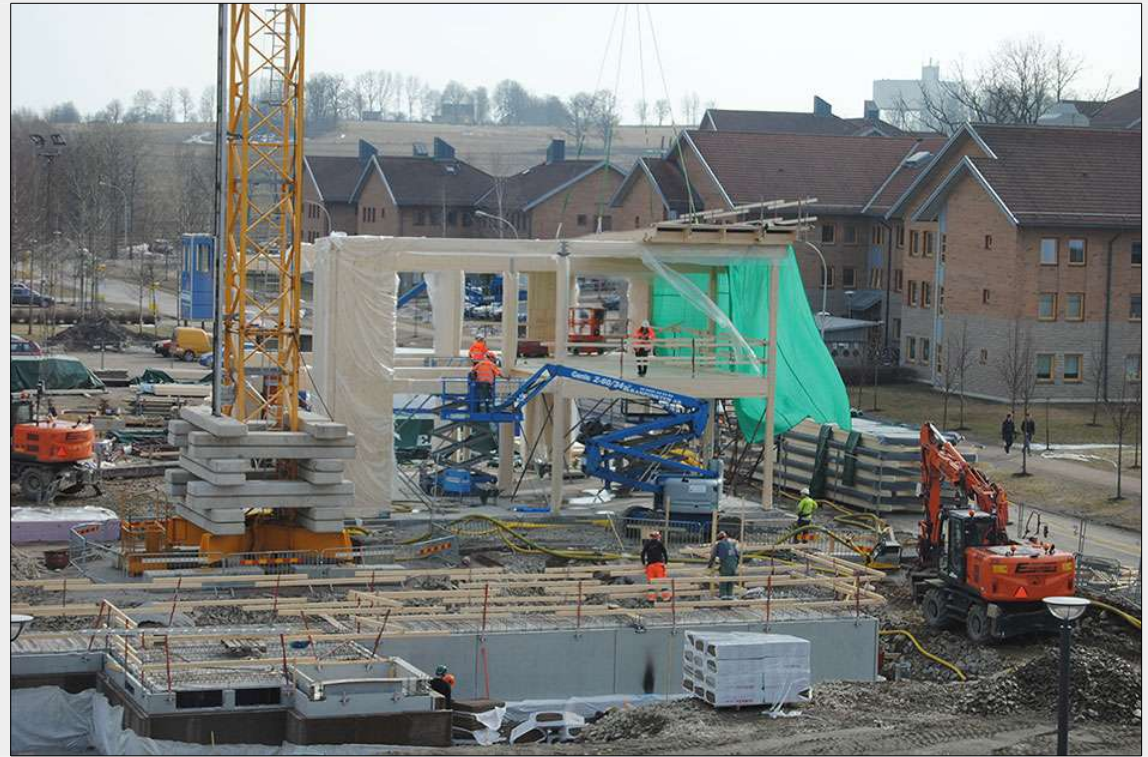

Fig. 5 - Glulam framework under erection for an educational building: "House N" at Linnaeus University in Växjö, Sweden (built in 2011).

strength, rigidity, lateral stability, wind resistance etc., but these systems must also satisfy modern criteria for fire safety, permissible sound levels and energy efficiency. Special consideration must be given to these functional criteria in the case of multi-storey buildings and well-tested technical solutions are now widely available.

Several timber-house companies in Slovenia and Sweden manufacture building elements such as roof trusses, joist floors and wall units themselves. In contrast, they almost always purchase the doors, windows and carpentry ready-made from external

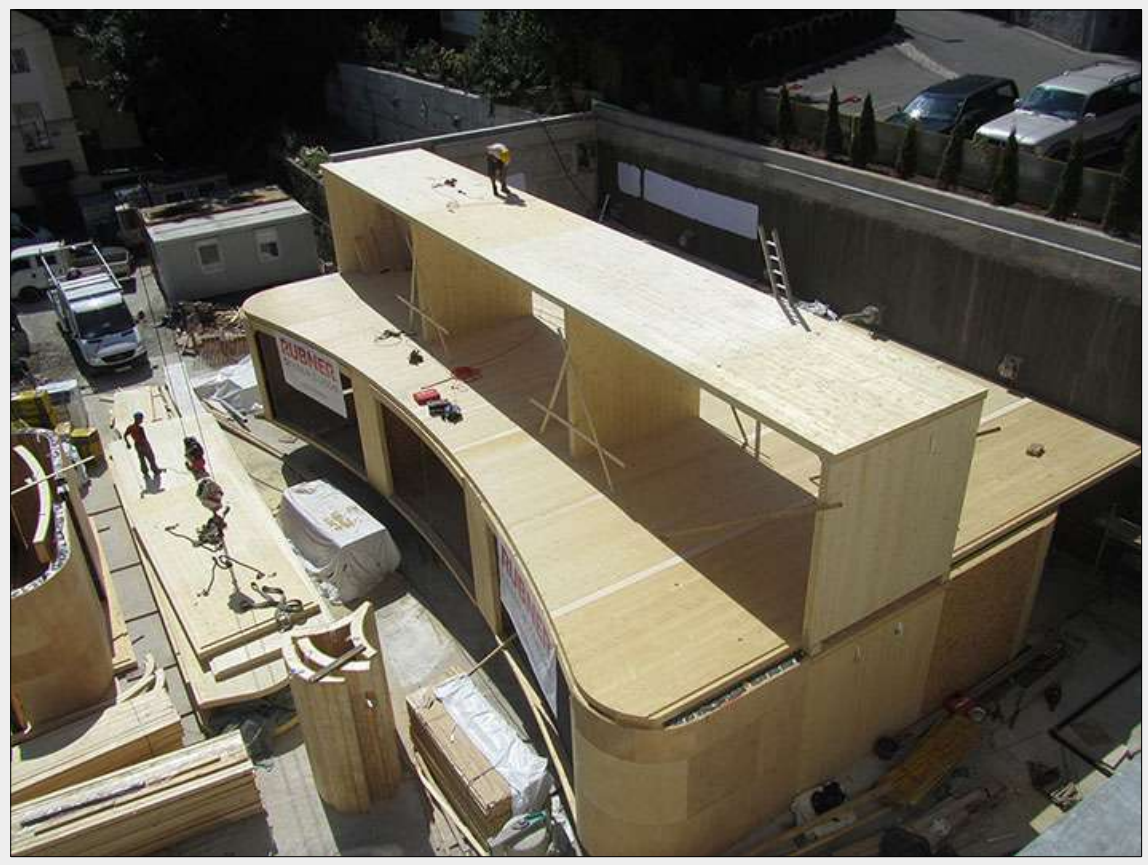

Fig. 6 - Prefabricated CLT elements are transported to the construction site and then assembled and erected manually: Waldorf School in Ljubljana, Slovenia built during 2009-2012. however have their origins in the traditions and company culture associated with single-family timber houses. During the manufacture of these CLT elements, the shapes are trimmed, openings are prepared for windows, doors, etc., and the thickness is levelled if necessary. Prefabricated CLT elements are delivered directly to the construction site.

In Slovenia there is no production of CLT, but Slovenian manufacturers have a close cooperation with Stora Enso, Hasslacher, $\mathrm{KLH}$ and the other producers, mostly in Austria. The CLT products are expected to play an important role in the future for single- and multi-storey timber buildings in Slovenia.

In the past 30 years, modern timber construction has undergone major changes, and the most important changes being the transition from on-site construction to factory prefabrication, the transition from elementary measures to modular building, and the development from a single-panel system based on small individual elements $(1.25$ to $1.30 \times 2.5$ to $2.65 \mathrm{~m})$ to a macropanel system. The macro-panel system provides the whole wall assemblies, including windows and doors, which are constructed in a horizontal plane in a factory and then transported to the building site.

These changes have greatly improved the efficiency of fabricating contemporary tim-

ber structures and present a great architectural potential for the $21^{\text {st }}$ century.

\section{Construction on-site}

The oldest method of construction is onsite, where the building materials are transported to the construction site and the various elements are then assembled and erected. The method requires a great deal of organization and planning on the building site, and risks associated with damage to materials and prefabricated structural components, and moisture damage must be considered. Of necessity, in large construction projects using e.g., CLT and glulam the degree of construction on-site occur (Fig. 6).

Of necessity, on-site construction tends to take a long time. In Slovenia, a non-negligible number of timber houses have appeared recently, constructed on-site by smaller tradesmen (carpentry workshops), but on-site construction is very rare in Sweden for single-family houses, although it occurs with larger buildings where the frame is of glulam or CLT.

\section{Off-site prefabrication}

In both Slovenia and Sweden, the trend is towards a higher degree of prefabrication where a greater part of the building work takes place at an industrial plant in a wellcontrolled environment with approved quality assurance. The on-site assembly of the building until the roof is laid then takes only one or two days. The prefabrication can include various components such as wall and floor elements, roofs, and trusses, 


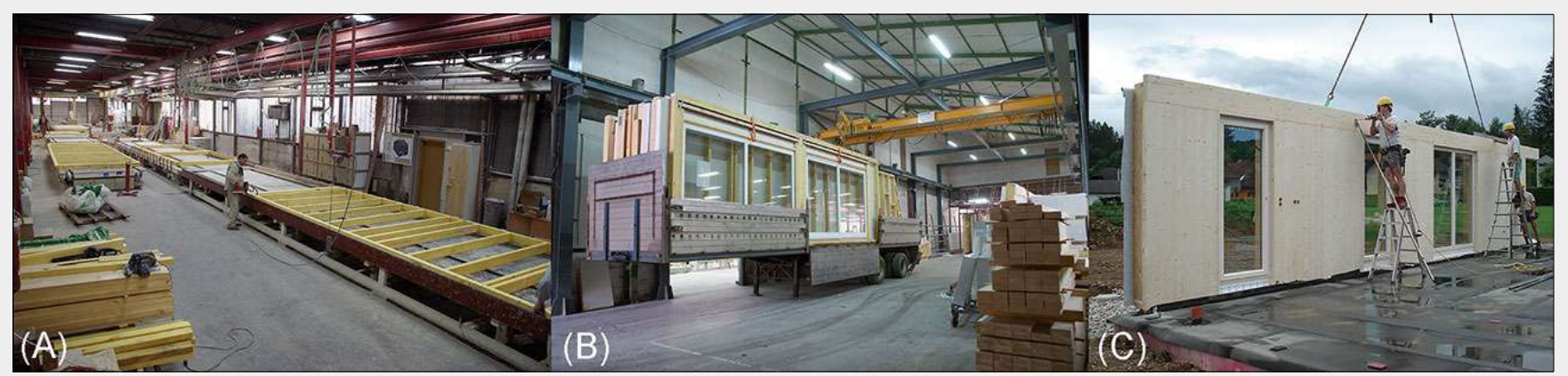

Fig. 7 - Examples of off-site prefabrication: (A) assembly of wall elements where the openings are constructed in a horizontal position; (B) wall elements on their way from the factory to the building site; and (C) assembly of modules. A building process with pre fabricated components or modules is faster, less weather-sensitive and provides a better control over the costs.

but also modules, so-called volumes. Both components and modules are prefabricated with insulation, installations, windows and doors etc. (Fig. 7).

Prefabricated components of wood have a low weight and can be erected to heights of several storeys using simple lifting equipment. With prefabricated modules, the total cost is up to $20-25 \%$ lower than building on-site, due partly to a time saving of up to $80 \%$. In Slovenia, most of the large house manufacturers offer off-site prefabricated houses, as well as in Sweden where off-site manufacture is totally dominating for single-family houses and this method of manufacture is also becoming more and more common for multi-storey housing built with different building systems.

\section{Modular systems}

Working with modular systems is a great help, since it is difficult to design traditionally and then translate the design of the building to an industrial context. With growing concern for sustainable forms, it is easier to adapt the construction and organisation of the building to the limits of the system from beginning. For example, the modules have to be of a size that can be transported on roads. The modules also have a more rigid construction than normal, which can be a challenge if the building height is restricted. In addition, the system requires an early commitment in the project, with very little scope for making changes later. The advantages of contemporary industrial timber constructions are a shorter time on the building site, less transport, less disruption for neighbours, good cost control and no drying time compared with that for in situ concrete, as shown in some recently awarded architectural projects (Fig. 8a-c.)

\section{Multi-storey buildings}

Extensive research has shown that material-neutral building regulations are preferable and, for over three decades, functionbased regulations have been common in Europe. This has led to an increase in the construction of multi-storey building, and the height of such buildings as well as proposed "vision projects" (Tab. 1).

Although the development and implementation of timber constructions in multistorey buildings is at different levels in different European countries (the permitted height of timber buildings is still restricted by law), the trend towards an increasing use of timber is clear. The main reasons for timber to be used for building are that it is renewable and available locally, and that it is beautiful, sensuous and has superb technical characteristics. The growing environmental awareness is also advantageous for wood as a construction material, where the choice is motivated by the fact that wood is a renewable material and that its use reduces $\mathrm{CO}_{2}$ emission, provided that the raw material is harvested in forests where sustainable forestry with replanting and management plans is practised. Timber construction also leads the way in terms of energy-efficient building. Many responsible contractors, architects and businesses now choose a timber construction because of its efficient use of both resources and money.

The increase can also be attributed to several other important factors, such as the lower cost of timber-buildings compared with construction using other materials, and the advantages of using timber in industrial building.

Of the primary design criteria (load-bearing strength, rigidity, lateral stability, wind resistance etc.), the question of lateral stability is especially important because the construction is light. A common practice in buildings with six or seven floors is to build the ground floor in concrete and secure the timber structure to the concrete. Wind loads are then transferred via joist elements and shear walls to the ground. Good stability is achieved by utilizing diaphragm action.

Although the trend is clear, there are still several technical problems to be solved before timber is again the major construction material in multi-storey constructions. The main areas for further development are:

- Fire protection: It has taken a long time to solve fire requirements in the initial projects. The impression is that the authorities involved were not used to inter-

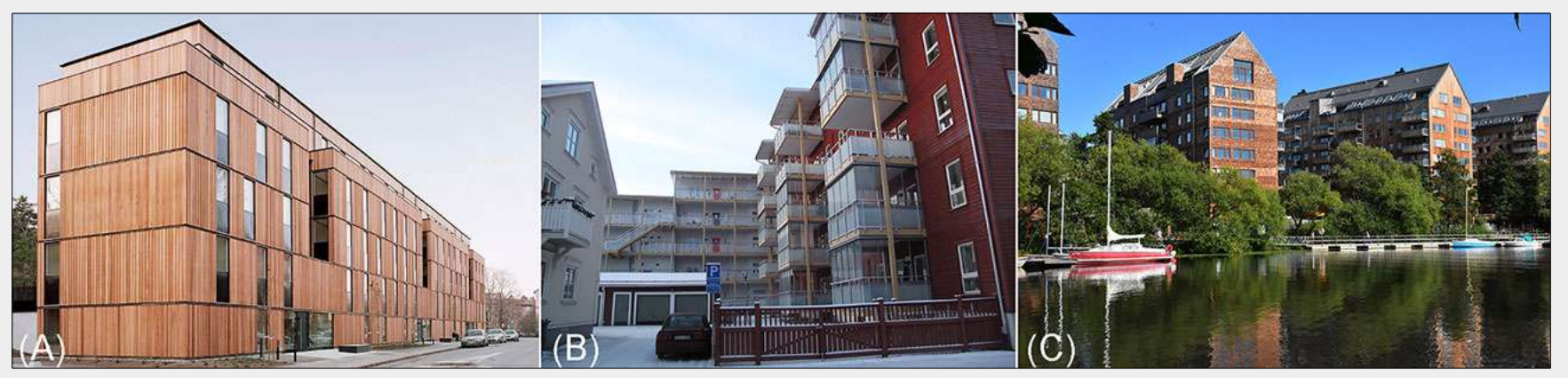

Fig. 8 - Examples of construction with modular systems in Sweden: (A) "Skagershuset", prefabricated modules from the company Moelven built in 2013; (B) "Ekorren", building system with glulam from the company Setra built in 2010; (C) "Strandparken", CLT construction from the company Martinsons built during 2012-2017. 
Tab. 1 - Present stage and future proposed suggestions for multi-storey timber buildings - "wooden skyscrapers".

\begin{tabular}{clcl}
\hline Competed & Building name & $\begin{array}{c}\text { Height } \\
\mathbf{( m )}\end{array}$ & Description \\
\hline 1995 & Wälludden & 12 & 5-storey residential building, Växjö, Sweden \\
$1995-2005$ & - & - & 3 -5 storey buildings in several European countries \\
$2006-2009$ & Limnologen & 22 & 8-storey residential building, Växjö, Sweden \\
2008 & e3-Berlin & 23 & 7-storey residential building, Berlin, Germany \\
2008 & Lagerhuset & 31 & 10-storey residential building, Eslöv, Sweden \\
2009 & Stadthaus & 30 & 9-storey residential building, London, UK \\
2012 & Holz8 (H8) & 21 & 8-storey residential building, Bad Aibing, Germany \\
2013 & Cenni di Cambiamento & 27 & 9-storey residential building, Milan, Italy \\
2013 & Forte tower & 32 & 10-storey residential building, Melbourne, Australia \\
2014 & Treet & 49 & 14-storey residential building, Bergen, Norway \\
2017 & Brock Commons & 53 & 18-storey residential building, Vancouver BC, Canada \\
2018 & HoHo & 84 & 24-storey office building, Vienna, Austria \\
Proposed & Barentshus & 80 & 24-storey office building, Kirkenes, Norway \\
Proposed & Abebe Court Tower & 87 & 26-storey residential building, Lagos, Nigeria \\
Proposed & HSB Wooden Skyscraper & 110 & 34-storey residential building, Stockholm, Sweden \\
Proposed & Baoab & 120 & 35-storey mix-purpose building, Paris, France \\
Proposed & Oakwood Tower & 300 & 80-storey residential building, London, UK \\
\hline
\end{tabular}

preting legislation as it applies to higher timber-framed residential buildings.

- Sound proofing: Insulation against noise transmission in timber buildings is another issue which requires further research to ensure a high-quality living environment.

- Prefabrication of elements: Construction time most be reduced and quality improved through off-site prefabrication.

- Installations: Installations should be integrated into the framework to a greater extent than today. A greater extent of prefabrication has been requested to avoid extensive subsequent installation

work at the construction site.

- Weather protection during the construction period should be specified at the planning stage and quality assured with flexible protection. Experience shows that protection by tents with overhead travelling cranes is a great benefit not only for a dry structure, but also for the work environment (see Fig. 4). The speed and ease with which the height can be increased is extremely important (Kitek Kuzman \& Sandberg 2016).

- Exterior façade maintenance: The cost of façade maintenance throughout the life cycle in relation to the cost of investment

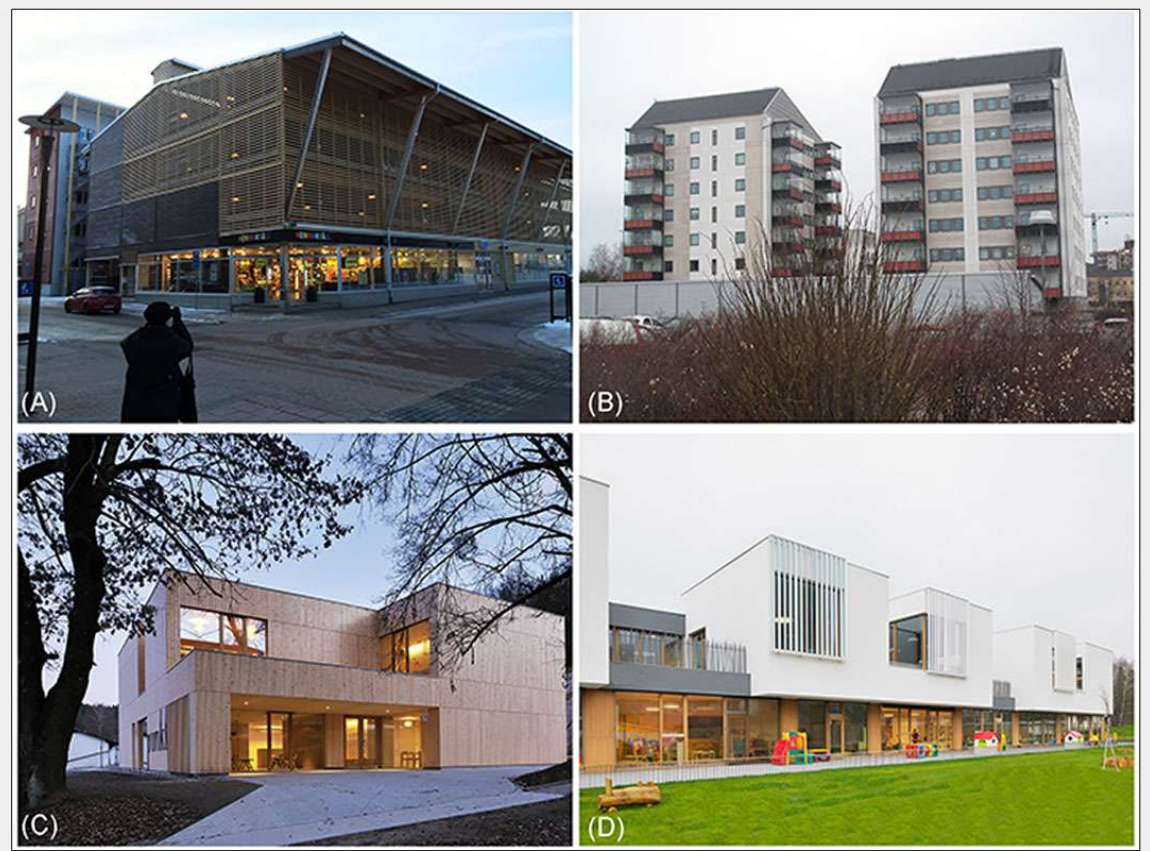

Fig. 9 - Multi-storey builings (CLT and CLT/Glulam constructions) in Sweden and Slovenia: (A) car park in the city block "Ekorren" in Skellefteå, Sweden, built in 2009; (B) the residential building "Portvaken" in Växjö, Sweden, built in 2009; (C) "Punkl" youth hostel in Ravne na Koroškem, Slovenia, built in 2011; and (D) the "Polzela Kindergarten" in Šoštanj, Slovenia, built in 2014. requires further monitoring. There is a risk that short-term decisions will create additional costs in the long term.

There are also other important questions such as how to increase the value of the whole design and construction process to the client, how to reduce the cost of timber building in use, and has to achieve greater regulatory harmonisation and produce authoritative national guidance documents. In Sweden, the market share of timber use in multi-storey buildings increased from $1 \%$ in 2000 to $15 \%$ in 2012 (Mahapatra et al. 2012), mostly four or more storeys (Fig. 9a-b), while in other countries, as in Slovenia, the growth has been very slow. In Slovenia there is only a very small share of timber multi-storey buildings; mostly twostorey buildings such as tourist facilities, schools and some residential buildings (Fig. 9c-d).

\section{Initiatives supporting the use of timber}

Positive aspects of wood as a structural material include its strength, environmentfriendliness, simple handling and appropriateness for industrial use, but a knowledge gap in timber engineering has led to a failure to use wood by engineers and architects. Attitudes towards timber construction also vary between Slovenia and Sweden. In Slovenia, people have concerns regarding fire safety and the durability of timber building, but this is not the case in Sweden (Hemström et al. 2014). To overcome these negative attitudes towards wood as a construction material, there are considerable activities both Slovenia and Sweden to promote the use of timber.

The latest European policy strategies and actions are affecting Slovenian research and development in the field of wood science and timber architecture. In 2008, the Slovenian Government adopted the $\mathrm{Na}$ tional Energy Efficiency Action Plan 20082016 (Anonymous 2008), the objective of 
which, in accordance with Directive 2006/ $32 / E C$, is to achieve a $9 \%$ saving of end-use energy through the implementation of planned instruments, which cover measures for efficient energy consumption, energy services, and the development of energy-efficient technologies and products (Anonymous 2006).

In 2008, in accordance with directives of the European Parliament and Council (EPBD) 2002/91/EC (Anonymous 2002) and EPBD 2010/31/EU (Anonymous 2010), Slovenia adopted the national construction legislation "Rules on efficient use of energy in buildings", which were amended and republished in 2010. The rules lay down the minimum technical requirements and guidelines for constructing low-energy houses today, where the energy consumption for heating today is approximately $40-$ $50 \mathrm{kWh} \mathrm{m} \mathrm{m}^{-2} \mathrm{a}^{-1}$ and will in future be nearly zero.

\section{Green public procurements}

Green public procurement in the construction sector in Slovenia is primarily affected and regulated by the technical specifications and criteria for buildings as specified in Annex 7 of the Decree Amending the Decree on Green Public Procurement (Anonymous 2011). In the category of buildings, it is generally required that $30 \%$ of inbuilt material (by volume) must be timber or timber-based ( $50 \%$ of this can be substituted by products with EcoLabels I or III). Furthermore, an award criterion gives additional credit if the 30\% minimum threshold for in-built material is exceeded.

\section{Economic incitements for timber buildings/constructions}

Like several other European countries, Slovenia is increasing the energy performance of buildings by encouraging investors or buyers to select more energy-efficient technologies through measures that make them more price-competitive, e.g., through low-interest loans or subsidies. In Slovenia, investors can receive low interest rate loans to build passive and very low-energy houses. Nowadays most timber houses built in Slovenia meet the requirements of the international passive house standard. The reason is that timber building manufacturers have a high knowledge level and tradition within this technology. Furthermore, lower interest-rate loans are also offered by the Slovenian Environmental Public Fund. These loans are intended for the construction or renovation of passive or very low-energy houses or for energy-efficiency measures (installation and replacement of solar collectors, biomass boilers, heat pumps, ventilation with recuperation, external building fixtures, heat insulation of the façade and roof) and for changing old windows with high quality wooden energy-efficient windows. From 2008 to 2011 the Slovenian Environmental Public Fund allocated $€ 21,832,400$ in loans and this led to savings of about 85,000
MWh in energy and about 13,000 tons of $\mathrm{CO}_{2}$.

Subsidies from the National Energy Efficiency Action Plan 2008-2016 (Anonymous 2008) also provide support for energy efficiency. These subsidies are available to those undertaking measures to improve energy efficiency, including the construction of passive and very low-energy houses and the comprehensive renovation of existing residential buildings. The subsidies have led to a significant increase in the number of passive timber houses and very low-energy timber houses in Slovenia (Praznik \& Zbašnik-Senegačnik 2015). The level of subsidies depends on the energy class of the renovated or newly built house and the type of heat insulation material. The highest subsidy, $€ 125$ per square metre of heated area, can be allocated for the construction of a residence in the lowest energy class (less than $10 \mathrm{kWh} \mathrm{m}^{-2} \mathrm{a}^{-1}$ ), insulated to at least $75 \%$ using material of natural origin (e.g., cellulose flakes, wood fibre, etc.). Subsidies are available for a maximum of $200 \mathrm{~m}^{2}$ of net heated area in the building. With optimal construction design and components, the subsidies may entirely cover the price difference between a passive timber house and a house built to the currently valid regulations.

\section{Award for wood construction}

The first National award for wood construction in Slovenia was presented in 2013 and the winners were selected by an interdisciplinary committee that included two architects, one expert from the field of sustainable construction and efficient energy use, one civil engineer and one expert from the carpentry sector. There were awards in four categories: residential buildings, public buildings, business-industrial buildings, and engineering works and technical solutions. This is awards event seeks to promote the positive image of wood, strengthen awareness about wood and encourage the use of wood both in construction and in everyday use.

\section{Other activities for wood promotion in Slovenia and Sweden}

The national action plan "Wood is beautiful" includes promotional activities that directly improve the state of the Slovenian wood-processing industry and improve the Slovenian transition to a low-carbon society.

SPIRIT Slovenia - Public Agency for Entrepreneurship, Internationalization, Foreign Investments and Technology - continues in 2017 to work on the promotion of wood and wood products with the aim to enhance the general awareness of wood and to encourage the use of wood in building construction, as well as to inform the public about many structural advantages of wood during construction, its positive effects on the micro-climate within the building, the fact that it is a sustainable and renewable building material, and social re- sponsibility in balancing environmental, social and economic values.

Ljubljana has been the European green capital in 2016 - the first and only green oasis in central and southeastern Europe. Ljubljana has 542 square meters of public green space per resident, while the city features 80 hectares of newly maintained green spaces, and green spaces are still being created from degraded urban land. Wood has a very special character in Ljubljana's green projects with a focus on the green city of tomorrow. Some showcase projects has been built as a dialog, showing that wood is the material of the future in urban construction and living, which will contribute in an essential way to new, cleaner and more healthful building practices.

In Sweden, a national strategy for "more wood in construction" was implemented in 2004, striving to further develop industrialized production processes (Platen \& Nord 2004). The vision of this strategy was that wood would be a self-evident material alternative in all construction work in Sweden within 10 to 15 years, and at a somewhat later date even in Europe. To reach this goal, operationalized objectives were formulated as follows:

- Increased competition in terms of construction materials and techniques. More choice alternatives will increase the competition on the market, and this can lead to decreasing costs and better products.

- The provision of new jobs by increasing the extent of further processing of wood as a raw material.

- A decrease in construction defects due to a greater degree of industrialized prefabrication. This has the advantage that construction elements can be built indoors, which leads to improved construction conditions for the product and a better work environment for the employees, which will improve quality control.

- Environmental protection by sustainable construction. Substituting steel and concrete with wood will reduce $\mathrm{CO}_{2}$ emissions considerably.

- Giving wood the chance to catch up with other construction materials that were treated preferentially due to the prohibition of wood in certain constructions.

In Sweden there is a wide range of programs to promote multi-storey wooden buildings.

\section{Swedish national wood construction strategy and its continuing training programme}

In 2006, the Swedish government appointed a National Wood Construction Strategy Committee, with the primary task of promoting the use of wood in apartment houses and public buildings. It is based on analyses carried out by the Swedish Ministry of Enterprise, Energy and Communications. A number of measures have been implemented within the framework of the strategy, including continuous 
training for those actively involved in the construction sector and "initiative projects" involving the construction of multistorey buildings in the towns of Växjö, Falun and Skellefteå. In addition, joint ac tion projects have resulted in the construc tion of buildings in several locations. In parallel with this, the timber industry is taking action through the Swedish Wood Construction Council. The two organisations have held a number of seminars and inspirational days throughout Sweden.

The National Wood Construction Strategy came to an end in December 2008. It is, however, continuing to operate under the name Wooden City 2012, a project which will involve further municipalities and regions. The Continuing Training Programme has been implemented jointly by Luleå University of Technology, Linnaeus University, University College Dalarna and RISE - Research Institutes of Sweden. This programme has been carried out in close collaboration with major wood construction projects in Skellefteå, Falun and Växjö, for the purpose of:

- monitoring and recording several aspects of wood construction projects, including residential quality, planning and decision;

- making process, technical/functional solutions, aesthetic aspects, the environment and life cycle targets, management and life-cycle economy, as well as wood system suppliers;

- making presentations and drawing conclusions at seminars held in connection with the construction project and at specialist workshops;

- ensuring the availability of records and information;

- providing a natural link with education and research at universities and institutes;

- creating the basis for the development of strong supplier groups in the wood construction sector (Bengtsson 2009).

\section{Nordic wooden cities}

The project "Nordic Wooden Cities" must also be mentioned. This project links together Sweden, Denmark, Norway, Finland and Iceland in a cooperation aiming at developing modern wooden cities. Wood should play a more central role in urban development in all kinds of buildings. A close collaboration on the political and administrative levels, information sharing, sharing of "best practice" experience in the whole range of the building process, innovation promoting and supporting cooperation between the public and private sectors are of utmost importance for the Nordic delegates involved in this project. Today, 17 members are engaged in "Nordic Wooden Cities", and new members are welcome to join (Nordic Wooden Cities 2017).

A similar approach has been successfully implemented by the project coordinator Hans Andrén in the "Välle broar" project in the municipality of Växjö, where the public sector, industry and academia have a com- mon ambition to lift wooden construction to the next level. All three sectors have a common denominator in triggering the use of wood in construction and the understanding that no sector can do everything on its own but that there is considerable benefit if the sectors work together. In that way, wood construction can be lifted to a higher level. Scandinavian countries might be an example for other European countries.

\section{Award for wood construction}

The Swedish Timber Prize is one of Sweden's biggest and most important architectural competitions, presented every four years to a building that represents good architecture in wood and that reflects and improves the times in which we live. The winner of the Swedish Timber Prize 2016 was the $12^{\text {th }}$ winner since 1967 . The Swedish Timber Prize was established by the Swedish Forest Industries Federation.

\section{Conclusions}

The development of timber building in Slovenia and Sweden after the functionbased building regulations that were introduced in Europe nearly three decades ago has been studied. It seems that the wood construction system in Sweden is passing from a formative to a growth phase, while in Slovenia it is still in the formative phase. Single-family wooden housing has a long tradition in both countries, but it is more dominant in Sweden than in Slovenia. Timber for multi-storey building structures has a market share of about 15\% in Sweden but is almost non-existent in Slovenia.

The use of timber in building structures is promoted to different degrees; in Sweden there is a wide range of programs to promote multi-storey timber buildings, whereas in Slovenia there is since 2014 a program to promote the use of wood in general, but not specifically for the construction of multi-storey buildings. In 2014, Slovenia also adopted the Green Public Procurement (GPP).

Long-term cooperative programs, including lobbying efforts and promotional campaigns are needed to make it possible to use traditional and new products that are ideally suited for contemporary residential and non-residential architecture.

There are numerous challenges associated with the construction of timber buildings, and these challenges are best met through further research using scientific examinations as a basis and more pilot projects presenting the technological potential, new production methods which allow completely new ways of building in wood making it superior to other building materials in economic and energy terms, to increase the knowledge of life cycle costs, construction costs, maintenance costs, sound and vibration, through the general increase in the number of timber buildings that are being erected.

We see opportunities for further develop- ment and future trends in high prefabrication, demanding architectural and constructional design, partnership and increased responsibilities for planning and construction, ownership interests within the building development team, and the improved and systematic feedback of experience. Nowdays, the opportunity to increase use of wood and new EWPs in biocultural society is to know users identity, values and life style. Demonstration projects are vital to show the various actors, e.g., the wood industry, architects and designers, builders, and housing associations, the technical and business potential of wood as a multi-purpose building material that should be used sensibly.

\section{Acknowledgements}

The authors would like to thank the STSM COST FP1407 and Slovenian Research Agency for financial support within the $\mathrm{P} 4$ 0015 program. Financial support from the Swedish Research Council Formas (projects EnWoBio 2014-172 and Experimental studies of capillary phenomena in bio-based materials 942-2016-64) is also gratefully acknowledged.

\section{References}

Anonymous (2002). Directive of the European Parliament and of the Council of 16 December 2002 on the energy performance of buildings. Official Journal of the European Communities L1: 65-71. [online] URL: http://eur-lex.europa.eu/ legal-content/EN/TXT/PDF/?uri=CELEX:32002Lo og\& from $=\mathrm{EN}$

Anonymous (2006). Directive 2006/32/EC of the European Parliament and of the Council of 5 April 2006 on energy end-use efficiency and energy services and repealing Council Directive 93/76/EEC. Official Journal of the European Union L114: 64-85.

Anonymous (2008). SLO National energy efficiency action plan of Slovenia. Mure-EEC, Republic of Slovenia, pp. 3. [online] URL: http:// http:// www.measures-odyssee-mure.eu/public/ mure_pdf/general/SLO3.PDF

Anonymous (2010). Directive of the European Parliament and of the council of 19 May 2010 on the energy performance of buildings (recast). Official Journal of the European Communities $L$ 153: 13-35. [online] URL: http://eur-lex.europa. eu/LexUriServ/LexUriServ.do?uri=OJ:L:2010:153: 0013:0035:en:PDF

Anonymous (2011). Uredba o zelenem javnem naročanju, stran 13611 [Regulation on green public procurement, page 13611]. Official Gazette no. 102/2011, Republic of Slovenia, pp. 158. [in Slovenian] [online] URL: https://www.urad ni-list.si/glasilo-uradni-list-rs/vsebina/106374 Bengtsson C (2009). Challenges in timber construction. In: Proceedings of the " $15^{\text {th }}$ International Timber Construction Forum (IHF)". Garmisch-Partenkirchen (Germany) 2-4 Dec 2009, pp. 11. [online] URL: http://www.forum-holz bau.com/pdf/ihfog_Bengtsson.pdf

Brandner R, Flatscher $G$, Ringhofer A, Schickhofer G, Thiel A (2016). Cross-laminated timber (CLT): overview and development. European Journal of Wood and Wood Products 74 (3): 
331-351. - doi: 10.1007/s00107-015-0999-5

Dol K, Haffner M (2010). Housing statistics in the European Union 2010. OTB Research Institute for the Built Environment, Delft University of Technology, Netherlands, pp. 150.

Eliasson L, Berg S, Sandberg D (2015). Some aspects on the more efficient use of wood in the industrial manufacture of single-family timber houses. ProLigno 11 (4): 418-425. [online] URL: http://www.diva-portal.org/smash/get/div a2:978838/FULLTEXT01.pdf

European Commission (1988). Council directive of 21 December 1988 on the approximation of laws, regulations and administrative provisions of the Member States relating to construction products. Official Journal of the European Communities L40: 12-26.

Ebner $G$ (2017). CLT production is expected to double until 2020. TIMBER-ONLINE.net, web site. [online] URL: https://www.timber-online. net/wood_products/2017/06/brettsperrholz- produktion-in-europa---20162020.html

Gabrijelcic P (2016). Energy and building aesthetics. Slovenian examples of good practice. Energy and Buildings 115: 36-46. - doi: 10.1016/j. enbuild.2014.12.040

Hemström K, Mahapatra K, Gustavsson L (2014). Public perceptions and acceptance of intensive forestry in Sweden. Ambio 43: 196-206. - doi: 10.1007/s13280-013-0411-9

Kitek Kuzman M, Sandberg D (2016). A new era for multi-storey timber buildings in Europe. In: Proceedings of the "New Horizons for the Forest Products Industry: $70^{\text {th }}$ Forest Products Society International Convention". Portland (OR, USA) 26-29 June 2016. Forest Products Society, Madison, WI, USA, pp. 7. [online] URL: http:// www.diva-portal.org/smash/record.jsf?pid=diva 2\%3A1004338

Mahapatra K, Gustavsson L, Hemström K (2012). Multi-storey wood-frame buildings in Germany, Sweden and the UK. Construction Innovation
12: 62-85. - doi: 10.1108/14714171211197508 Nordic Wooden Cities (2017). Nordic Wooden Cities - a nordic cooperation. Web site. [online] URL: http://www.nordicwoodencities.com/ Platen FV, Nord T (2004). Mer trä i byggandet Underlag för en nationell strategi att främja användning av trä i byggandet [More timber in construction - Basis for a national strategy to promote the use of timber in construction]. Government office of Sweden, Ministry of Enterprise, Energy and Communications, Sweden, pp. 165. [in Swedish]

Praznik M, Zbašnik-Senegačnik M (2015). The embodied primary energy and optimisation of energy-efficient houses. Gradevinar 67 (9): 853864. - doi: 10.14256/JCE.1193.2014

PURES (2010). Rules on energy efficiency in buildings. Web Site. [online] URL: http://www. pisrs.si/Pis.web/pregledPredpisa?id=PRAV10043 